\title{
The South African business CyCle: WHAT has CHANGed?
}

\author{
Philippe Burger \\ Department of Economics, University of the Free State
}

Accepted September 2009

\begin{abstract}
This paper identifies the basic empirical characteristics and changes of the South African business cycle since 1960. As such, the paper examines changes in volatility as well as the co-movement between several national account variables and real GDP. To examine the co-movements the paper follows Kydland and Prescott, Gavin and Kydland as well as Bergman, Bordo and Jonung and uses correlation coefficients and Granger causality tests. Following Ramos, the paper extends the results of the Granger causality tests using variance decomposition analysis in the context of a VAR (vector auto regression) to establish the contribution that selected national account variables make to the $\mathrm{h}$-period-ahead forecast error variance of themselves and the other variables included in the VARs. The paper indicates that since 1994 volatility in the South African economy decreased significantly, while durable consumption appears to lead the business cycle.
\end{abstract}

Keywords: Volatility, business cycle

JEL E32, 53

\section{Introduction}

Interest in business cycle behaviour has been rekindled during the last two decades. Kydland and Prescott (1990:3-4) note that business cycle research in the 1950s-70s focused either on creating business cycle theory, or empirical work that was based on structural systems of behavioural equations, themselves based on the theory. Little empirical research took the form of reporting the data without imposing a probability model on it. Kydland and Prescott argue that there is not just room, but, indeed, a need for such research dedicated to establishing the empirical characteristics of business cycles. They continue that the need arises from wrong assumptions often made in the past about the co-movement between variables (Kydland \& Prescott, 1990:4). They furthermore state that to first identify the empirical characteristics of the business cycle lays the groundwork to creating theory that will explain these empirical characteristics. Given that such an approach was followed fruitfully in neoclassical growth theory, with Solow building his theory on empirical characteristics identified by others, Kydland and Prescott (1990:3) argue that it might be just as fruitful in business cycle research. Moreover, this approach by Kydland and Prescott represents a return to the original approach followed by Burns and Mitchell (1946) in their seminal work on business cycles.

This paper seeks to contribute to the literature on the South African business cycle by identifying the basic empirical characteristics and the changes in the characteristics of the business cycle in a manner similar to Kydland and Prescott (1990) as well as Gavin and Kydland (2000). As such, the paper examines the correlation and co-movement between several national account variables and real GDP.

\section{2}

\section{The empirical approach}

Gavin and Kydland (2000) continue with the Kydland and Prescott empirical approach to 
business cycle research when they consider how US business cycles differed prior to and after 1979, the year that the Federal Reserve in the US initiated its strong anti-inflationary stance. Other authors also continue with this approach, most notably in the last decade, to identify what has happened to business cycle volatility. Most of the research focuses on the US and finds that the volatility of GDP growth and the output gap has decreased significantly since the mid-1980s (cf. Romer, 1999; McConnell \& Perez-Quiros, 2000; Warnock \& Warnock, 2000; Taylor, 2000; Kahn, McConnell \& Perez-Quiros, 2002; 2001, Blanchard \& Simon, 2001; Stock \& Watson, 2003a and 2003b, Gordon, 2005). Some authors compared G7 countries to establish whether or not volatility also decreased in these countries (Bergman, Bordo \& Jonung, 1998, Doyle \& Faust, 2002, Barrell \& Gottschalk, 2004).

The empirical approach states as few priors and imposes as few limitations on models as possible in an attempt to identify patterns in observed data. Thus, the approach is inductive by nature. This explains why Kydland and Prescott (1990), Bergman, Bordo and Jonung (1998), as well as Gavin and Kydland (2000) focus on correlations, cross-correlations and standard deviations of time-series to identify co-movements between variables as well as the volatility characteristics of individual series.
This is also the approach followed in this paper, before it moves on to a VAR analysis and the accompanying impulse-response functions and variance decompositions.

Contrary to the recent upsurge in business cycle research in the US and G7, business cycle research in South Africa is a rather underdeveloped field, with only a handful of authors working on the South African business cycle. These include work by the South African Reserve Bank (SARB), most notably by Venter (2005), discussing the measurement of the business cycle. Recent contributions from outside the SARB include Du Plessis and Smit (2007) and Du Plessis (2006), whose work, in addition to focusing on the cyclicality of South African monetary and fiscal policy, also suggests and applies an alternative approach to the determination of business cycle turning points.

This paper considers the period 1960:1 to 2006:4. Though a host of other variables can be considered when characterising the business cycle, due to limitations of space this paper has a national accounts focus and therefore focuses specifically on GDP and the components of aggregate expenditure (e.g. consumption, investment, as well as their subcomponents). ${ }^{1}$ All variables are in real terms and the source for all data is the South African Reserve Bank (SARB) online download facility.

\section{Figure 1}

The real GDP gap and the SARB cycles

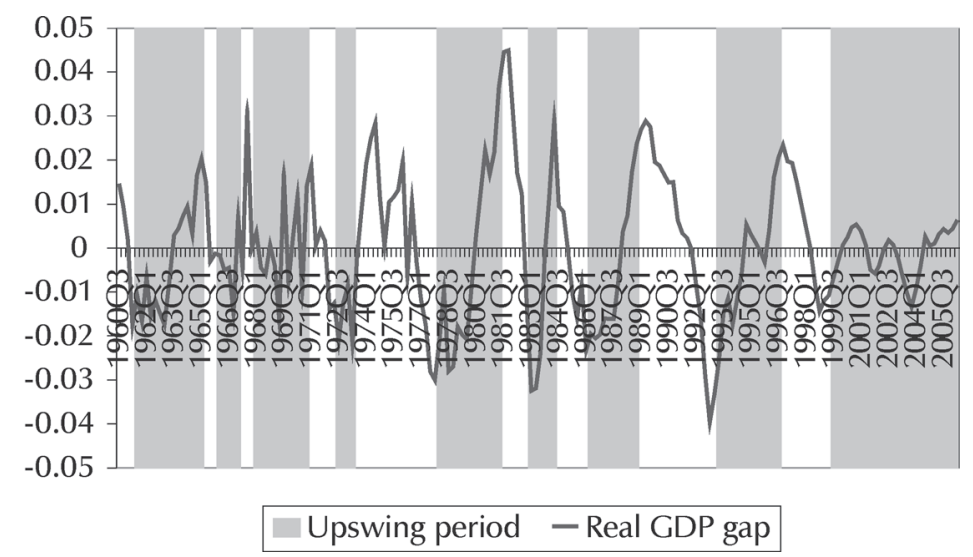




\section{Figure 2}

The SARB and HP cycle periods

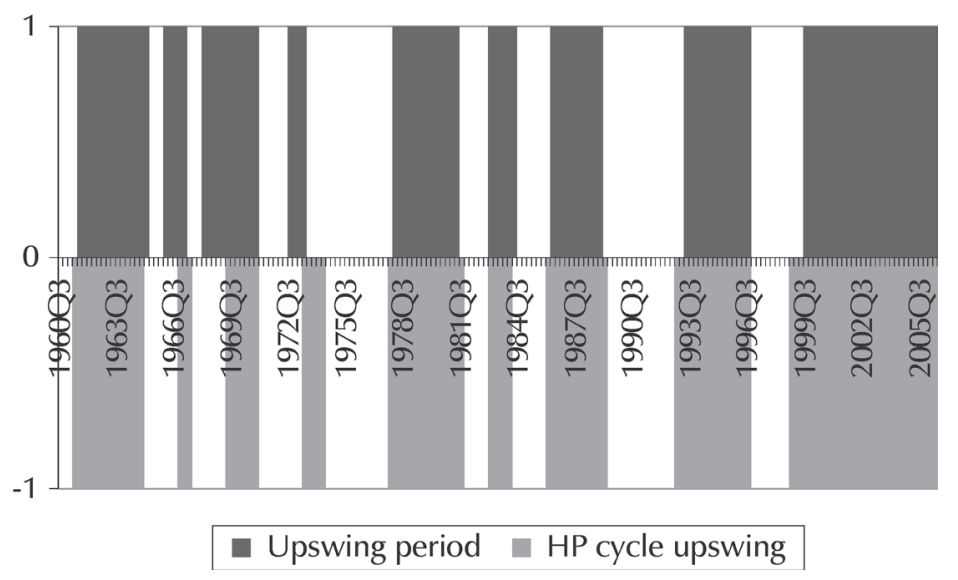

To detrend the data and isolate the cyclical components of the series, the paper uses a Hodrick-Prescott filter (in this it follows, among others, Kydland \& Prescott). ${ }^{2}$ Fig 1 compares the real GDP output gap as estimated using a HP filter with the upswing and downswing periods as identified by the SARB. Fig 2 shows the upswing and downswing periods identified by the SARB and the upswing and downswing periods identified by the HP filter. ${ }^{3}$ (The SARB identifies official turning points after a statistical analysis of approximately 230 time series as well as consideration of economic events in the vicinity of a possible turning point.) The upswings and downswings identified by the SARB and the HP filter largely overlap.

As mentioned above, the objective of the paper is to establish which characteristics of the business cycle changed. As such, the paper needs to compare the characteristics of different sub-periods of the overall sample, which requires the division of the total sample into sub-periods. However, the literature contains different approaches to do this division. For the US Blanchard and Simon (2001), Stock and Watson (2003a) and Gordon (2005) use the mid-1980s as a break because the 20-quarter moving standard deviation of US output clearly decreases in the mid-1980s. In contrast Romer (1999), Bergman et al. (1998) and Taylor (1998) merely compare pre-WWI (e.g. 1880-1914) and post-WWII periods (i.e. post-1945) (with some consideration for the interwar period). Given that South African national accounts data start only in 1946 for annual data and 1960 for quarterly data it is not possible to compare pre-WWI and post-WWII periods. Thus, the paper opts for the simple approach, similar to Blanchard and Simon (2001), Stock and Watson (2003a) and Gordon (2005), of looking at a graph to identify periods of low and high volatility.

When inspecting the movements in the output gap from 1960 to 2006, the period 1960 to the mid-1970s and the period since the mid1990s has much less output volatility than the period between the mid-1970s and the mid1990s. After the transformation of the output gap values into Z-values, Figure 3 shows that throughout the total period 1960:3 to 2006:2, economic upswings reached standard deviations of between one-and-a-half and two, while in the periods up to the mid-1970s and since the mid-1990s economic downswings almost never exceeded one standard deviation. This contrasts sharply with the period between the mid-1970s and the mid-1990s when economic downswings often came close to or exceeded two standard deviations.

The period of higher volatility commences with the Soweto uprising that occurred in June 1976, after which followed a period of 
political turmoil in South Africa. This turmoil and together with it the volatility ended with the first democratic election in April 1994. Therefore, based on the historical markers of the Soweto uprising and the first election, the paper sub-divides the sample into the subperiods 1960:3-1976:2, 1976:3-1994:1 and 1994:2-2006:2.

Figure 3

The real GDP gap (Z-values)

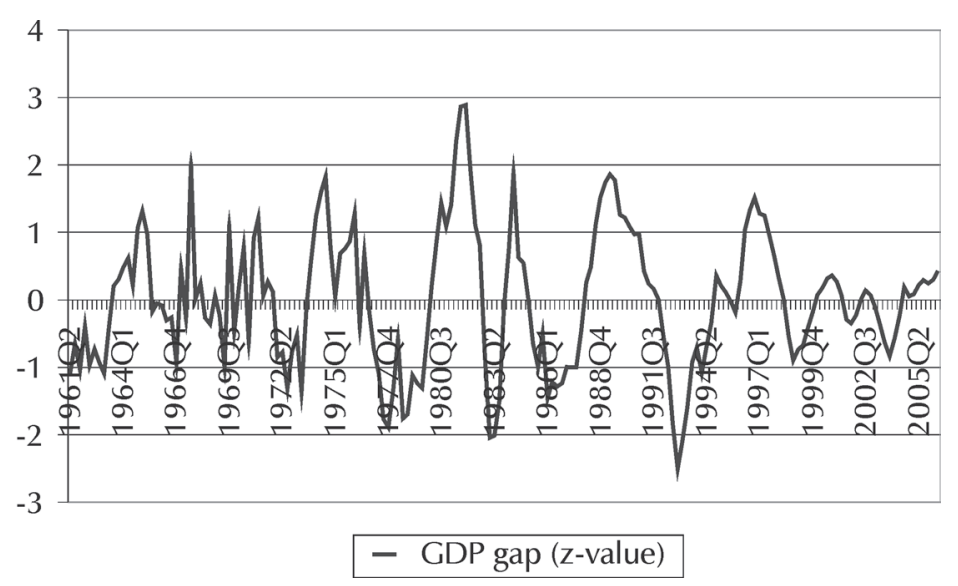

3

\section{Cross-correlations and Granger causality tests}

To consider the co-movement between time series for each of the three periods, the paper calculates the cross-correlation coefficients between the real GDP gap and the contemporaneous gap as well as five leads and lags of the gaps of the other variables, each time for the three periods. ${ }^{4}$ This is the same approach as Kydland and Prescott (1990) and Gavin and Kydland (2000), with Bergman et al. (1998) following a similar approach but with fewer lags. Besides the cross-correlations, the paper also explores whether or not the volatility of the other variables displays changes between the three periods that are similar to that of the real GDP gap.

Although the leads and lags of the crosscorrelations may provide an indication of the sequence of changes in the gap variables relative to changes in the real GDP gap, the paper follows in the spirit of Bergman et al. (1998) and also runs Granger causality tests in this section between the real GDP gap and the gap variables used to calculate the cross-correlations. The Granger tests may give a better indication of not necessarily causality between variables, but the sequencing of changes in variables relative to GDP. The tables containing the Granger causality test results are reported in Appendix A.

In the following section the paper extends the Granger causality analysis by also estimating a set of VARs. On these VARs the paper then performs variance decompositions to establish the contribution that a variable makes to the h-period-ahead forecast error variance of itself and the other variables included in the VAR. According to Ramos (2003), whether or not a variable explains the majority of its own forecast error variance, will determine whether or not that variable will be considered exogenous in the Granger sense.

\subsection{GDP and the components of expenditure on GDP}

Though GDP is the key variable considered when exploring the business cycle (because it represents national income), it is by no 
means the only one, particularly because the business cycle is defined as the co-movement of several economic variables (usually seen as a co-movement of variables with real GDP growth or its gap). Hence, the question is which variables display such a co-movement and how similar is their behaviour to that of real GDP? More specifically, to what extent do the cyclical movements of real GDP lead, lag or coincide with the cyclical movements of other variables? Table 1 presents the correlation coefficients between the real GDP gap in time $\mathrm{t}$ and the leads (time $\mathrm{t}-5$ to $\mathrm{t}-1$ ), lags (time $\mathrm{t}+1$ to $t+5$ ) and contemporaneous (time $t$ ) values of variables such as consumption and investment. Correlation coefficients that are statistically significant at the 5 per cent level are shaded in grey.

Table 1

Correlation coefficients of GDP and its components

\begin{tabular}{|c|c|c|c|c|c|c|c|c|c|c|c|}
\hline \multicolumn{12}{|c|}{ Correlation coefficient of cross correlation with GDP in time $t$} \\
\hline Per 1 & t-5 & $t-4$ & $t-3$ & $t-2$ & $t-1$ & $\mathbf{t}$ & $t+1$ & $\mathbf{t}+2$ & $t+3$ & $t+4$ & $\mathbf{t}+\mathbf{5}$ \\
\hline $\mathrm{C}$ & 0.17 & 0.23 & 0.30 & 0.44 & 0.49 & 0.48 & 0.37 & 0.21 & 0.21 & 0.00 & -0.07 \\
\hline G & -0.06 & -0.21 & -0.08 & -0.02 & -0.07 & 0.08 & 0.13 & 0.12 & 0.19 & 0.23 & 0.17 \\
\hline I & -0.20 & -0.13 & 0.06 & 0.25 & 0.28 & 0.40 & 0.43 & 0.44 & 0.46 & 0.41 & 0.23 \\
\hline$X$ & 0.12 & -0.16 & -0.30 & -0.12 & -0.34 & -0.20 & -0.22 & -0.33 & -0.09 & -0.10 & -0.09 \\
\hline$M$ & -0.17 & 0.06 & 0.29 & 0.40 & 0.57 & 0.67 & 0.56 & 0.48 & 0.31 & 0.05 & -0.08 \\
\hline Per 2 & $t-5$ & $t-4$ & $t-3$ & $t-2$ & $t-1$ & $\mathbf{t}$ & $t+1$ & $t+2$ & $t+3$ & $t+4$ & $t+5$ \\
\hline $\mathrm{C}$ & 0.01 & 0.21 & 0.42 & 0.59 & 0.73 & 0.81 & 0.72 & 0.59 & 0.45 & 0.34 & 0.24 \\
\hline G & -0.13 & -0.13 & -0.04 & 0.08 & 0.14 & 0.13 & 0.13 & 0.13 & 0.06 & -0.06 & -0.04 \\
\hline I & -0.01 & 0.17 & 0.34 & 0.51 & 0.65 & 0.76 & 0.77 & 0.76 & 0.66 & 0.53 & 0.39 \\
\hline$x$ & 0.16 & 0.15 & 0.12 & 0.11 & 0.05 & 0.07 & -0.04 & -0.07 & -0.14 & -0.22 & -0.21 \\
\hline$M$ & 0.11 & 0.29 & 0.49 & 0.68 & 0.77 & 0.79 & 0.70 & 0.50 & 0.26 & 0.02 & -0.12 \\
\hline Per 3 & $t-5$ & $t-4$ & $t-3$ & $t-2$ & $t-1$ & $\mathbf{t}$ & $t+1$ & $t+2$ & $t+3$ & $t+4$ & $t+5$ \\
\hline C & 0.17 & 0.34 & 0.48 & 0.58 & 0.70 & 0.78 & 0.75 & 0.63 & 0.47 & 0.31 & 0.15 \\
\hline G & -0.50 & -0.39 & -0.16 & 0.11 & 0.28 & 0.34 & 0.35 & 0.30 & 0.24 & 0.18 & 0.13 \\
\hline I & 0.06 & 0.06 & 0.08 & 0.15 & 0.31 & 0.49 & 0.59 & 0.65 & 0.64 & 0.57 & 0.51 \\
\hline$X$ & -0.05 & -0.07 & 0.01 & 0.10 & 0.24 & 0.44 & 0.42 & 0.26 & 0.24 & 0.21 & 0.04 \\
\hline$M$ & 0.23 & 0.23 & 0.27 & 0.32 & 0.45 & 0.55 & 0.54 & 0.47 & 0.42 & 0.41 & 0.35 \\
\hline
\end{tabular}

C: Consumption by households, G: Government consumption, I: Investment, X: Exports, M: Imports Correlations: Probabilities lower than 5 per cent indicated by shaded area

Whereas leads and lags of the cross-correlations provide an indication of whether changes in a variable lead or lag changes in the real GDP gap, the Granger causality tests provide a more rigorous examination of the leads and lags. If a variable displays high cross-correlations with the real GDP gap, while the Granger tests yield statistically significant results, it serves as evidence that the changes in the variables lead or lag changes in the real GDP gap. However, if variables display high cross-correlations with the real GDP gap, while none of the Granger causality tests yields statistically significant results, it is taken as evidence that changes in 
the variables are contemporaneous with changes in the real GDP gap. Table A1 in Appendix A reports the probabilities of the Granger causality tests conducted between the real GDP gap and the real gap variables of the aggregate expenditure components. The Granger tests were run four times, including two, four, six and eight lags. The results for four, six and eight lags are very similar, so only the two and four lags are reported in Appendix A.

The correlation coefficients between the real GDP gap and the gap variables of the main components of aggregate expenditure indicate that a strong contemporaneous correlation exists in all periods between the real GDP gap and the gaps for consumption, imports and investment (see Table 1). The lags and leads of these variables also display strong correlations with the real GDP gap. A relationship between the real GDP gap and the export gap seems to be absent during the first and second periods, while the correlations between the real GDP gap and the contemporaneous value and the first lag of the gap for exports $(t$ and $t+1)$ in the third period exceeds 0.4 . This finding goes against conventional wisdom, as it is often assumed that the foreign business cycle leads the South African business cycle via an increase in South African exports (cf. Barr \& Kantor, 2002:59-60). However, the finding is similar to Du Plessis (2006:769-70) who finds a low concordance of export and output cycles. Though Kabundi (2009:1) finds that exports do play a role in the synchronisation of US and SA business cycles, he also finds that "...there is a decrease in integration over time translated by a drop in synchronisation of cycles". Government consumption expenditure displays a weak, if not absent correlation in the first and second periods, and a positive correlation in the third period. Du Plessis, Smit and Sturzenegger (2007) also find pro-cyclicality in the behaviour of fiscal policy, especially in more recent periods, though Thornton (2007) finds the opposite.

Exploring the question regarding leads and lags further, the Granger causality tests reported in Table A1 in Appendix A indicate that in the first and third period changes in the consumption gap led changes in the real GDP gap. Not only do the Granger causality tests indicate that changes in the consumption gap precede changes in the real GDP gap in the third period, but they report bidirectional causality. In the second and third period and counter to what would be expected on a priori grounds, changes in the investment gap lagged changes in the real GDP gap. The same is true for exports in the third period. As with investment, changes in the import gap lag changes in the real GDP gap during the second and third period. However, unlike investment, this accords with a priori expectation.

Although the differences in the correlation coefficients between the periods on first appearance are not that stark, moving from the second to the third period there was a significant reduction in the standard deviations of some of the gaps of the components of aggregate expenditure. This reduction coincided with the decrease in the standard deviation of the real GDP gap itself (see Table B1 in Appendix B). More specifically, in the third period the standard deviations of the real GDP gap as well as of the consumption, investment and import gaps - which are also the three variables that display the highest correlation coefficients with the real GDP gap - are approximately 50 per cent or less of what they were in the second period. (The differences are statistically significant at the 5 per cent level as indicated by the F-tests that test for whether or not the variances between two periods are statistically significantly different - see Table B1 in Appendix $\mathrm{B}$ for more detail). Compared to the first period, the standard deviations of these three variables are also lower than during the second period (with the difference also being statistically significant at the 5 per cent level as indicated by the F-tests). The second period seems to be the most turbulent, with its standard deviations not only much higher than those in the third period, but also slightly higher than what they were in the first period. When comparing the second and third periods, the government consumption and export gaps, which are also the variables that displayed the lowest correlations with the real GDP gap, do not display the same large decrease in their standard deviations. Lastly, the standard deviation of investment is significantly higher than that of consumption. This accords 
with both $a$ priori expectation and investment and consumption behaviour in, for instance, the US (cf. Kydland \& Prescott, 1990:11 and Gavin \& Kydland, 2000:Fig 2).

The standard deviations of the gaps of the aggregate expenditure components are also much larger than the standard deviation of the real GDP gap (see Table B1 in Appendix B). The lower standard deviation of the real GDP gap relative to the expenditure component variables indicates the effect of the co-variances between variables to reduce the overall volatility of the GDP gap. The difference between the standard deviations of several of the aggregate expenditure components and of the real GDP gap is similar to the behaviour of these same variables in other countries (cf. Kydland \& Prescott, 1990:11; Bergman et al., 1998:79, Gavin \& Prescott, 2000:Fig 2). For instance, for the 1960 to 2006 period the ratio of the investment gap standard deviation to the real GDP gap standard deviation is 3.7 for South Africa, compared to the 4.9 found by Kydland and Prescott for the US for the period 1954 to 1989 (Kydland \& Prescott, 1990:7). The components whose gaps display the highest standard deviations are the investment and import gaps. The relatively higher volatility of investment is similar to investment behaviour in other countries where the volatility of investment also exceeds that of, for instance, consumption (cf. Kydland \& Prescott, 1990:11; Gavin \& Prescott, 2000:Fig 2).
Therefore, to conclude, those components that display the highest correlations with the real GDP gap are also those components that register a reduction in their volatility that coincide with the reduction in the volatility of the real GDP gap. These components are consumption, investment and imports. In the case of exports, it also appears as if an increase in correlation with the real GDP gap coincides with a reduction in the standard deviation of exports. As Doyle and Faust (2002:431) note, this is not necessarily surprising because the correlation coefficient equals the co-variance of two variables divided by the product of their standard deviations. Thus, if the standard deviation of one or both decreases, while their co-variance remains unchanged, the correlation coefficient will improve.

To consider the strengths of correlation coefficients and the reduction in volatility further, the paper analyses the different components of consumption and investment. This may trace the origins of the reduced volatility better and indicate which components of investment and consumption display the strongest cyclical behaviour.

\subsection{Consumption}

This section seeks to trace the behaviour of household consumption discussed above to the behaviour of the components of consumption. These components are durable, semi-durable and non-durable consumption goods, as well as services.

\section{Table 2}

Correlation coefficients of the components of consumption

\begin{tabular}{|c|c|c|c|c|c|c|c|c|c|c|c|}
\hline \multicolumn{12}{|c|}{ Correlation coefficient of cross correlation with GDP in time $t$} \\
\hline Period 1 & $t-5$ & $t-4$ & $t-3$ & $t-2$ & $t-1$ & $\mathbf{t}$ & $t+1$ & $t+2$ & $t+3$ & $t+4$ & $t+5$ \\
\hline Durable & 0.27 & 0.40 & 0.42 & 0.54 & 0.53 & 0.47 & 0.28 & 0.13 & 0.09 & -0.07 & -0.12 \\
\hline $\begin{array}{l}\text { Semi- } \\
\text { durable }\end{array}$ & -0.10 & 0.09 & 0.18 & 0.36 & 0.37 & 0.46 & 0.49 & 0.40 & 0.31 & 0.26 & 0.08 \\
\hline $\begin{array}{l}\text { Non- } \\
\text { durable }\end{array}$ & 0.04 & 0.06 & 0.11 & 0.30 & 0.27 & 0.35 & 0.27 & 0.23 & 0.21 & 0.00 & -0.02 \\
\hline Services & 0.11 & 0.03 & 0.11 & 0.04 & 0.27 & 0.19 & 0.23 & 0.05 & 0.12 & -0.01 & -0.07 \\
\hline
\end{tabular}




\begin{tabular}{|c|c|c|c|c|c|c|c|c|c|c|c|}
\hline Period 2 & $t-5$ & $t-4$ & $t-3$ & $t-2$ & $t-1$ & $\mathbf{t}$ & $t+1$ & $t+2$ & $t+3$ & $t+4$ & $t+5$ \\
\hline Durable & 0.25 & 0.41 & 0.55 & 0.60 & 0.63 & 0.65 & 0.48 & 0.33 & 0.22 & 0.15 & 0.12 \\
\hline $\begin{array}{l}\text { Semi- } \\
\text { durable }\end{array}$ & 0.05 & 0.26 & 0.47 & 0.61 & 0.70 & 0.75 & 0.70 & 0.63 & 0.54 & 0.46 & 0.34 \\
\hline $\begin{array}{l}\text { Non- } \\
\text { durable }\end{array}$ & -0.18 & -0.08 & 0.11 & 0.32 & 0.50 & 0.64 & 0.63 & 0.58 & 0.47 & 0.38 & 0.24 \\
\hline Services & -0.09 & 0.09 & 0.23 & 0.41 & 0.56 & 0.63 & 0.63 & 0.49 & 0.37 & 0.26 & 0.19 \\
\hline Period 3 & $t-5$ & $t-4$ & $t-3$ & $t-2$ & $t-1$ & $\mathbf{t}$ & $t+1$ & $t+2$ & $t+3$ & $t+4$ & $t+5$ \\
\hline Durable & 0.18 & 0.39 & 0.55 & 0.67 & 0.75 & 0.79 & 0.73 & 0.58 & 0.33 & 0.06 & -0.17 \\
\hline $\begin{array}{l}\text { Semi- } \\
\text { durable }\end{array}$ & 0.10 & 0.14 & 0.18 & 0.24 & 0.34 & 0.38 & 0.30 & 0.21 & 0.13 & 0.08 & 0.10 \\
\hline $\begin{array}{l}\text { Non- } \\
\text { durable }\end{array}$ & 0.03 & 0.11 & 0.20 & 0.30 & 0.44 & 0.57 & 0.62 & 0.62 & 0.60 & 0.56 & 0.51 \\
\hline Services & 0.19 & 0.30 & 0.35 & 0.32 & 0.28 & 0.23 & 0.19 & 0.06 & -0.08 & -0.16 & -0.28 \\
\hline
\end{tabular}

Type of consumption good listed in first column.

Correlations: Probabilities lower than 5 per cent indicated by shaded area

Table B2 in Appendix B indicates that during the second period the standard deviation of the gaps of all the components of consumption increased relative to the first period, and then fell during the third period. The decrease from the second to the third period was larger than the increase from the first to the second period. In the case of all the components, with the exception of non-durable consumption, the standard deviation decreased by 50 per cent or more. Durable consumption goods displayed the highest volatility, followed by semi-durable consumption goods. This is as expected because the more durable consumption goods are, the more they are expected to behave like investment goods. The standard deviation of the durable consumption goods gap is also similar, if not slightly higher, than that of the investment gap.

How do the correlation coefficients between the gaps of the consumption components and the real GDP gap compare? Table 2 indicates that in all periods the leads of the durable consumption gap seem to be stronger than the lags. This is confirmed further by the Granger causality tests for the first and the third period, with the Granger test with two lags indicating bidirectional causality during the third period (see Table A2 in Appendix A). During the second period the semi-durable goods gap displays high cross-correlations with the real GDP gap, with the highest for the contemporaneous gap values of semi-durable goods and real GDP. The Granger test with four lags points to causality running from the semi-durable consumption gap to the real GDP gap. Though correlated with the real GDP gap, the Granger tests indicate that the non-durables gap did not lead or lag changes in the GDP gap.

\subsection{Investment by sector}

Just as the previous section seeks to trace the behaviour of household consumption to the behaviour of the components of consumption, this section seeks to trace the behaviour of investment to the components of investment. However, there are various ways in which investment can be sub-divided. The data of the SARB divides it in three ways: by sector, by institution and by asset type. The paper uses the sub-division of investment in terms of sector and by asset type to consider the behaviour of investment relative to the business cycle (real GDP gap). It does not use the sub-division of investment by institution (dividing investment into the investment by 
general government, the private sector and public corporations) because the private sector largely encompasses the financial sector, the manufacturing sector and several of the other sectors delineated in the sectoral sub-division. The sectors covered are community, social and personal services; electricity, gas and water; financial intermediation, insurance, real estate and business services; manufacturing; mining and quarrying as well as transport, storage and communication.

Just as the volatility of the gaps of the components of expenditure on real GDP usually exceeds the volatility of the real GDP gap, so the volatility of the gaps of the sectoral components of investment exceeds that of the investment gap (see Table B3 in Appendix B). The standard deviations of all sectors changed in the second period compared to the first, though, except for the increase in the volatility in manufacturing, all these changes are statistically insignificant. With the exception of the electricity sector (with a statistically insignificant increase) and transport (with a statistically insignificant decrease), the standard deviations of all the components registered decreases in the third period that were statistically significant. Proportionally the largest decrease occurred in manufacturing, which experienced a decrease in volatility of more than 75 per cent. Financial services experienced decrease of almost 50 per cent, while the decrease in mining and community services was less spectacular. The large decrease in manufacturing volatility corresponds with the experience of the US (cf. Warnock \& Warnock, 2000).

In all three periods the financial sector registers strong correlations, while mining in the second and manufacturing in the third and to a more limited extent in the second period register strong cross-correlations (see Table 3 ). The Granger causality tests indicate that in the first and second period changes in the financial sector led changes in the real GDP gap (Table A3 in Appendix A). The more important role of manufacturing is also apparent in the Granger test (with four lags) that indicate that in the third period changes in the manufacturing investment gap led changes in the real GDP gap. Furthermore, as Tables 3 and A3 in Appendix 3 show, in the third period changes in the electricity sectors, typically a sector dominated by government, tend not to lag or lead changes in the real GDP gap (though they are positively correlated to the real GDP gap), ${ }^{5}$ while changes in the transport sector, another governmentdominated sector, seem to lag changes in real GDP.

Table 3

Correlation coefficients of the sectoral components of investment

\begin{tabular}{|lcccccccccccc|}
\hline \multicolumn{10}{|c|}{ Correlation coefficient of cross correlation with GDP in time $\mathbf{t}$} \\
\hline \multicolumn{1}{|c}{ Period 1 } & $\mathbf{t}-\mathbf{5}$ & $\mathbf{t}-\mathbf{4}$ & $\mathbf{t}-\mathbf{3}$ & $\mathbf{t}-\mathbf{2}$ & $\mathbf{t}-\mathbf{1}$ & $\mathbf{t}$ & $\mathbf{t}+\mathbf{1}$ & $\mathbf{t + 2}$ & $\mathbf{t + 3}$ & $\mathbf{t + 4}$ & $\mathbf{t + 5}$ \\
Community & -0.20 & -0.36 & -0.31 & -0.18 & -0.26 & -0.13 & 0.00 & 0.19 & 0.35 & 0.43 & 0.43 \\
Electricity & -0.16 & -0.27 & -0.17 & -0.27 & -0.44 & -0.24 & -0.13 & -0.04 & 0.07 & 0.13 & 0.15 \\
Financial services & -0.08 & 0.12 & 0.30 & 0.40 & 0.54 & 0.58 & 0.56 & 0.37 & 0.20 & -0.02 & -0.09 \\
Manufacturing & 0.08 & 0.14 & 0.30 & 0.38 & 0.41 & 0.36 & 0.30 & 0.23 & 0.16 & 0.08 & -0.09 \\
Mining & -0.30 & -0.17 & -0.10 & 0.17 & 0.14 & 0.44 & 0.35 & 0.45 & 0.34 & 0.45 & 0.23 \\
Transport & -0.10 & -0.04 & -0.08 & 0.01 & 0.07 & 0.08 & 0.17 & 0.24 & 0.37 & 0.35 & 0.24 \\
\hline
\end{tabular}




\begin{tabular}{|lccccccccccc|}
\hline \multicolumn{1}{|c}{ Period 2 } & $\mathbf{t}-\mathbf{5}$ & $\mathbf{t}-\mathbf{4}$ & $\mathbf{t}-\mathbf{3}$ & $\mathbf{t}-\mathbf{2}$ & $\mathbf{t}-\mathbf{1}$ & $\mathbf{t}$ & $\mathbf{t + 1}$ & $\mathbf{t + 2}$ & $\mathbf{t + 3}$ & $\mathbf{t + 4}$ & $\mathbf{t + 5}$ \\
Community & -0.04 & 0.08 & 0.17 & 0.31 & 0.44 & 0.55 & 0.59 & 0.57 & 0.46 & 0.25 & 0.13 \\
Electricity & -0.15 & -0.16 & -0.15 & -0.10 & -0.05 & -0.01 & 0.06 & 0.15 & 0.12 & 0.08 & 0.08 \\
Financial services & 0.12 & 0.30 & 0.49 & 0.63 & 0.72 & 0.72 & 0.63 & 0.49 & 0.34 & 0.22 & 0.12 \\
Manufactu-ring & 0.16 & 0.28 & 0.38 & 0.46 & 0.51 & 0.57 & 0.57 & 0.55 & 0.47 & 0.39 & 0.31 \\
Mining & 0.08 & 0.21 & 0.32 & 0.45 & 0.52 & 0.65 & 0.63 & 0.58 & 0.46 & 0.35 & 0.17 \\
Transport & -0.34 & -0.29 & -0.23 & -0.12 & -0.01 & 0.14 & 0.25 & 0.36 & 0.46 & 0.41 & 0.33 \\
\hline \multicolumn{1}{|c|}{ Period 3 } & $\mathbf{t - 5}$ & $\mathbf{t}-\mathbf{4}$ & $\mathbf{t - 3}$ & $\mathbf{t}-\mathbf{2}$ & $\mathbf{t - 1}$ & $\mathbf{t}$ & $\mathbf{t + 1}$ & $\mathbf{t + 2}$ & $\mathbf{t + 3}$ & $\mathbf{t + 4}$ & $\mathbf{t + 5}$ \\
Community & -0.16 & -0.12 & -0.10 & -0.03 & 0.16 & 0.36 & 0.47 & 0.42 & 0.19 & -0.04 & -0.05 \\
Electricity & 0.22 & 0.27 & 0.31 & 0.35 & 0.38 & 0.40 & 0.42 & 0.40 & 0.34 & 0.25 & 0.19 \\
Financial services & -0.03 & 0.05 & 0.19 & 0.37 & 0.56 & 0.70 & 0.74 & 0.72 & 0.62 & 0.49 & 0.33 \\
\hline Manufactu-ring & 0.40 & 0.47 & 0.49 & 0.51 & 0.60 & 0.65 & 0.53 & 0.40 & 0.29 & 0.17 & 0.06 \\
\hline Mining & -0.25 & -0.34 & -0.36 & -0.38 & -0.29 & -0.16 & -0.06 & 0.11 & 0.31 & 0.41 & 0.40 \\
Transport & -0.17 & -0.33 & -0.46 & -0.53 & -0.52 & -0.40 & -0.16 & 0.13 & 0.37 & 0.53 & 0.62 \\
\hline
\end{tabular}

Sector listed in first column.

Correlations: Probabilities lower than 5 per cent indicated by shaded area

\subsection{Investment by asset type}

Dividing investment by asset, yields five types of assets; construction works, machinery, nonresidential buildings, residential buildings and transport equipment. With the exception of residential buildings, the standard deviations of the gaps of all asset types increased from the first to the second period, though only those of construction and non-residential investment are statistically significant (see Table B4 in Appendix B). In contrast, the standard deviation of the gaps of all asset types decreased from the second to the third period (see Table B4 in Appendix B). From the second to the third period the standard deviation of machinery and nonresidential buildings decreased by approximately 50 per cent, while that of transport equipment decreased by between 40 per cent and 45 per cent. The standard deviation of the gaps of construction equipment and residential buildings also decreased, but by not as much.

Table 4 shows that machinery and residential construction displayed the highest correlations with the real GDP gap in the first period. In the second period most types of investment displayed high correlations with the real GDP gap, while in the third period residential and non-residential construction, as well as machinery displayed the highest correlations. Table A4 in Appendix A, reporting the Granger causality tests, indicate that in the first period the changes in machinery, residential and non-residential investment led the real GDP gap, while in the third period it is only non-residential investment.

For both the second and third period the Granger causality test indicates that changes in the transport equipment gap lag changes in the real GDP gap. In addition, the Granger causality tests indicate that changes in the gap variables for investment in machinery, as well as residential and non-residential investment lag changes in the real GDP gap in the second period. Thus, the evidence highlights the lagging nature of all these components (with a few exceptions such as non-residential investment in the third period) and, as such, indicates that investment in general does not lead the business cycle in South Africa. 
Table 4

Correlation coefficients of the asset components of investment

\begin{tabular}{|c|c|c|c|c|c|c|c|c|c|c|c|}
\hline \multicolumn{12}{|c|}{ Correlation coefficient of cross correlation with GDP in time $t$} \\
\hline Period 1 & t-5 & $t-4$ & t-3 & t-2 & t-1 & $\mathbf{t}$ & $\mathbf{t}+\mathbf{1}$ & $\mathbf{t}+\mathbf{2}$ & $t+3$ & $t+4$ & $\mathbf{t}+5$ \\
\hline Construction & -0.29 & -0.20 & -0.21 & 0.05 & -0.07 & 0.05 & 0.13 & 0.23 & 0.38 & 0.51 & 0.40 \\
\hline Machinery & -0.10 & 0.00 & 0.23 & 0.42 & 0.48 & 0.56 & 0.49 & 0.42 & 0.36 & 0.32 & 0.08 \\
\hline $\begin{array}{l}\text { Non- } \\
\text { residential }\end{array}$ & -0.18 & -0.27 & -0.09 & 0.03 & -0.02 & 0.14 & 0.11 & 0.20 & 0.25 & 0.18 & 0.14 \\
\hline Residential & -0.17 & -0.08 & 0.10 & 0.19 & 0.38 & 0.47 & 0.57 & 0.54 & 0.41 & 0.20 & 0.10 \\
\hline Transport & -0.06 & -0.08 & -0.07 & -0.08 & -0.04 & 0.04 & 0.15 & 0.23 & 0.30 & 0.30 & 0.15 \\
\hline Period 2 & $t-5$ & $t-4$ & $t-3$ & $t-2$ & $t-1$ & $\mathbf{t}$ & $t+1$ & $t+2$ & $t+3$ & $t+4$ & $t+5$ \\
\hline Construction & 0.02 & 0.20 & 0.29 & 0.39 & 0.49 & 0.57 & 0.57 & 0.57 & 0.49 & 0.38 & 0.29 \\
\hline Machinery & 0.07 & 0.18 & 0.33 & 0.48 & 0.59 & 0.69 & 0.68 & 0.67 & 0.54 & 0.40 & 0.26 \\
\hline $\begin{array}{l}\text { Non- } \\
\text { residential }\end{array}$ & -0.28 & -0.23 & -0.12 & 0.04 & 0.22 & 0.38 & 0.51 & 0.58 & 0.63 & 0.63 & 0.58 \\
\hline Residential & 0.12 & 0.24 & 0.34 & 0.43 & 0.46 & 0.44 & 0.38 & 0.24 & 0.10 & -0.01 & -0.09 \\
\hline Transport & -0.12 & 0.06 & 0.22 & 0.37 & 0.46 & 0.54 & 0.54 & 0.54 & 0.51 & 0.42 & 0.30 \\
\hline Period 3 & $t-5$ & $t-4$ & $t-3$ & $t-2$ & $t-1$ & $\mathbf{t}$ & $t+1$ & $t+2$ & $t+3$ & $t+4$ & $\mathbf{t}+5$ \\
\hline Construction & -0.32 & -0.28 & -0.18 & -0.08 & 0.06 & 0.21 & 0.30 & 0.32 & 0.30 & 0.25 & 0.27 \\
\hline Machinery & 0.16 & 0.12 & 0.11 & 0.12 & 0.25 & 0.39 & 0.38 & 0.43 & 0.51 & 0.49 & 0.50 \\
\hline $\begin{array}{l}\text { Non- } \\
\text { residential }\end{array}$ & 0.35 & 0.46 & 0.43 & 0.46 & 0.47 & 0.47 & 0.50 & 0.45 & 0.30 & 0.20 & 0.07 \\
\hline Residential & -0.05 & 0.00 & 0.14 & 0.33 & 0.55 & 0.69 & 0.75 & 0.65 & 0.47 & 0.27 & 0.04 \\
\hline Transport & 0.02 & -0.06 & -0.14 & -0.16 & -0.12 & 0.02 & 0.25 & 0.44 & 0.48 & 0.50 & 0.45 \\
\hline
\end{tabular}

Type of asset/investment listed in first column.

Construction and transport are construction equipment and transport equipment.

Correlations: Probabilities lower than 5 per cent indicated by shaded area

\section{4}

\section{The variance decomposition}

Ramos (2003:105) argues that a variance decomposition constitutes an alternative method to investigate Granger causality. ${ }^{6}$ A variance decomposition estimates the relative contribution that variables in VAR equations make to the forecast error variance of the dependent variables of the equations. If the variance decomposition shows that a significant part of the variance of a variable is explained by its own innovation, that variable is exogenous in the Granger causality sense. Following this suggestion, the section takes the Granger causality analysis, conducted above, one step further. It estimates a series of VARs that contain the real GDP gap as well as the variables that according to analysis above, Granger cause and are Granger caused by the real GDP gap. On the basis of these VARs the section conducts variance decompositions of the VARs to explore the exogeneity/endogeneity of the variables and thereby seeks to confirm the findings of the Granger causality tests. The decision as to whether or not a variable is exogenous depends 
on what proportion of its own forecast error variance a variable explains. Ramos (2003:107) argues that in a one-year-ahead forecast in a six variable VAR, 50 per cent is high. The analysis in this paper also uses 50 per cent as cut-off point. However, instead of a one-year-ahead forecast, this paper uses a 12-quarters-ahead forecast since 12 quarters is the length of time that it takes for the contributions of most of the variables to the forecast error variances to stabilise.

The section estimates three sets of VARs for each of the three periods. The first combines the real GDP gap and the gaps for consumption, investment, imports and, for the third period, exports. The other two sets of VARs also include the real GDP gap and the import gap in the first and second periods and the real GDP gap, import and export gaps in the third period. However, they replace the gaps for consumption and investment with the gaps of the components of consumption (e.g. durable consumption) and investment (e.g. manufacturing sector investment) that Granger cause and are Granger caused by the real GDP gap. Both sets of VARs include the gaps for durable consumption in the first and third periods and semi-durable consumption and services in the second period. What distinguishes the two sets is the components of investment that they include. The first includes the sectoral components of investment, while the second includes the asset type components. Given that the focus is on the variance decompositions and because of the rather bulky nature of the tables containing the VARs, the section does not present the VAR tables, but only the variance decompositions. ${ }^{7}$

\subsection{VARs using the GDP gap and the gaps of the GDP components}

The discussion above indicates that in all three periods the gaps of consumption, investment and imports either Granger cause the real GDP gap or are Granger caused by the real GDP gap. Therefore, this section estimates a VAR for each of the three periods, containing these variables. In addition, based on the results of the Granger causality, the VAR for the third period also includes the export gap. The lag length of each of the three VARs was selected on the basis of information criteria such as the Akaike and the Schwartz information criteria. On the basis of these criteria the section estimated VARs with three, four and five lags for the first, second and third periods respectively. In addition, given the argument made by some that the South African business cycle was typically export led (cf. Barr \& Kantor, 2002:59-60), the section also presents the variance decomposition of VARs for the first and second period that contain the export gap in addition to the gaps of real GDP, consumption, investment and imports. These VARs were estimated with three and two lags for periods one and two, with the number of lags selected on the basis of information criteria. Table 5 presents the results after 12 quarters. The first column of each period in Table 5 shows the variable of which the variance is explained, while the subsequent columns list the contribution of each of the variables to the variance being explained. Note that rows add up to 100 per cent.

Using 50 per cent as a cut-off point for exogeneity, the above analysis indicates that relative to the variables used in the VAR, the GDP gap was exogenous in the first and second periods (Table 5 with or without the inclusion of exports), but endogenous in the third period (Table 5). In the third period the gap for consumption explains 40.98 per cent of the forecast error variance of the real GDP gap, which is approximately the same proportion as the GDP gap explains of its own forecast error variance. The consumption gap itself is endogenous in both the second and third periods (see Table 5 with or without the inclusion of exports). In the second period approximately $50-55$ per cent of the variance of the consumption gap is explained by the shock to the real GDP gap (Table 5 with or without the inclusion of exports). Including the gap for exports in the VARs of the first and second periods shows that the export gap was strongly exogenous, explaining 70.4 per cent and 88 per cent of its own forecast error variance (see Table 5). In contrast to the first and second periods, exports become endogenous in the third period (Table 5), with the real GDP gap explaining 32.9 per cent of the forecast error variance of exports. 


\section{Table 5}

Variance decomposition of the VARs using the GDP gap and GDP components

\begin{tabular}{|c|c|c|c|c|c|c|c|c|c|c|}
\hline \multicolumn{11}{|c|}{$\begin{array}{l}\text { Variance decomposition of the VARs using the GDP gap and the gaps of consumption, } \\
\text { investment and imports }\end{array}$} \\
\hline \multicolumn{5}{|c|}{ Period 1} & \multicolumn{5}{|c|}{ Period 2} & \\
\hline & GDP & C & I & $\mathbf{M}$ & & GDP & C & I & $\mathbf{M}$ & \\
\hline GDP & 69.77 & 20.42 & 2.03 & 7.78 & GDP & 71.25 & 6.85 & 17.41 & 4.49 & \\
\hline C & 17.85 & 75.75 & 4.39 & 2.01 & C & 49.37 & 30.73 & 17.73 & 2.18 & \\
\hline I & 17.72 & 48.50 & 26.94 & 6.85 & I & 48.06 & 15.07 & 36.47 & 0.39 & \\
\hline $\mathbf{M}$ & 30.32 & 35.68 & 2.03 & 31.98 & $\mathbf{M}$ & 42.69 & 10.48 & 14.21 & 32.63 & \\
\hline
\end{tabular}

\begin{tabular}{|c|c|c|c|c|c|c|c|c|c|c|c|c|c|c|c|c|c|}
\hline \multicolumn{18}{|c|}{$\begin{array}{l}\text { Variance decomposition of the VARs using the GDP gap and the gaps of consumption, } \\
\text { investment and imports }\end{array}$} \\
\hline \multicolumn{6}{|c|}{ Period 1} & \multicolumn{6}{|c|}{ Period 2} & \multicolumn{6}{|c|}{ Period 3} \\
\hline & GDP & C & I & $\mathbf{M}$ & $\mathbf{X}$ & & GDP & C & I & $\mathbf{M}$ & $\mathbf{X}$ & & GDP & C & I & $\mathbf{M}$ & $\mathbf{x}$ \\
\hline GDP & 66.44 & 18.90 & 1.98 & 8.98 & 3.71 & GDP & 75.61 & 2.76 & 3.67 & 12.33 & 5.64 & GDP & 39.60 & 40.98 & 4.19 & 10.17 & 5.06 \\
\hline C & 15.15 & 73.01 & 5.75 & 1.77 & 4.33 & C & 54.07 & 33.06 & 8.91 & 2.51 & 1.45 & C & 40.623 & 33.52 & 6.54 & 10.99 & 8.32 \\
\hline I & 16.87 & 40.56 & 30.09 & 8.13 & 4.35 & I & 51.54 & 7.683 & 32.70 & 5.73 & 2.35 & I & 43.15 & 11.44 & 18.25 & 14.951 & 12.22 \\
\hline $\mathbf{M}$ & 26.83 & 33.36 & 2.783 & 32.88 & 4.14 & $\mathbf{M}$ & 47.94 & 3.87 & 4.44 & 39.19 & 4.55 & $\mathbf{M}$ & 45.30 & 7.97 & 15.26 & 18.271 & 13.20 \\
\hline $\mathbf{x}$ & 8.41 & 5.33 & 2.331 & 13.52 & 70.41 & $x$ & 3.18 & 4.40 & 1.39 & 3.08 & 87.95 & $x$ & 32.881 & 13.62 & 16.44 & 16.732 & 20.34 \\
\hline
\end{tabular}

Variance decomposition for VAR without exports after 12 periods with Cholesky ordering: GDP, consumption, investment, imports and exports

Variance decomposition for VAR with exports after 12 periods with Cholesky ordering: GDP, consumption, investment, imports and exports

Tables 5 also show that the inclusion of exports in the VARs of the first and second period does not add much, with exports never explaining more than 6 per cent of the forecast error variance of any of the other variables. Its inclusion in the third period, though allowing one to indicate that exports itself has become endogenous, adds only modestly to the explanation of the other variables. The export gap never explains more than 14 per cent of the forecast error variance of the other variables (see Table 5). The real GDP gap explains more than 40 per cent of the forecast error variance of investment and imports in both the second and third periods.

To consider how long it takes for a shock to die out once it affects the system the paper also estimates impulse response functions. These functions indicate that, for example, in the second period the effect on the consumption gap of a one standard deviation shock to the real GDP gap dies out after 20 quarters (see Appendix C). In the third period it takes about 16-20 quarters for the effect of a one standard deviation shock to the real GDP gap on the gaps of consumption, imports and investment to die out, as well as the effect of a one standard deviation shock to the consumption gap on the real GDP gap (see Appendix D).

\subsection{VARs using the gaps of the components of consumption and the sectoral components of investments}

The discussion about the presence of Granger causality between the real GDP gap and the gaps of the components of consumption indicated that in the first and third periods the gaps for 
durable consumption and in the second period semi-durable consumption and services either Granger caused or were Granger caused by the real GDP gap. As such, these components of consumption were included in the VARs estimated in this subsection and the next subsection. These VARs also include the gaps for the real GDP and imports, while the third period VAR also includes the export gap. In addition, this subsection includes sectoral components of investment that also either Granger caused or were Granger caused by the real GDP gap. In the first period, these are investment in the electricity, financial services and mining sectors. In the second period they include investment in community services, financial services, mining and transport, while in the third they include investment in community services, financial services, transport and manufacturing. The information criteria were used to select the number of lags to include in the VARs. This lead to the selection of two, four and two lags for the first, second and third periods. Table 6 presents the variance decomposition of the VARs after 12 quarters.

Using 50 per cent as cut-off point, the outstanding features of period one is that the gaps for real GDP, durable consumption and electricity are all exogenous in the Granger sense (with mining virtually equal to 50 per cent), while the durable consumption gap explains 60.1 per cent of the forecast error variance of the gap of investment in the financial services sector (see Table 6).

Table 6

Variance decomposition: Periods $1-3$

\begin{tabular}{|ccccccc|}
\hline & \multicolumn{7}{c|}{ Period 1 } \\
\hline GDP & Dur cons & Elec & Fin serv & Mining & Imports \\
GDP & 55.04 & 30.19 & 8.21 & 2.44 & 1.87 & 2.25 \\
Dur cons & 2.78 & 91.26 & 3.54 & 0.85 & 0.29 & 1.27 \\
Elec & 4.17 & 16.66 & 69.00 & 5.86 & 3.36 & 0.95 \\
Fin serv & 4.60 & 60.07 & 4.98 & 25.88 & 2.11 & 2.36 \\
Mining & 8.28 & 38.29 & 1.50 & 0.69 & 49.20 & 2.04 \\
Imports & 14.28 & 43.34 & 5.59 & 1.43 & 2.65 & 32.71 \\
\hline
\end{tabular}

Period 1: Variance decomposition after 12 periods with Cholesky ordering: GDP, durable consumption, electricity, financial services, mining and imports

\begin{tabular}{|crrrrrrrrr|}
\hline & \multicolumn{7}{c|}{ Period 2 } \\
\hline GDP & Com & Fin serv & Min & Trans & S-dur cons & Serv & Imp \\
Com & 46.85 & 4.95 & 11.96 & 2.30 & 3.82 & 19.09 & 6.94 & 4.08 \\
Fin serv & 16.69 & 46.93 & 11.25 & 4.62 & 7.18 & 5.38 & 4.54 & 3.41 \\
Mining & 17.65 & 10.59 & 27.87 & 4.78 & 12.51 & 20.48 & 3.53 & 2.60 \\
Trans & 35.53 & 5.98 & 9.14 & 28.91 & 4.92 & 5.25 & 6.66 & 3.61 \\
Semi-dur cons & 13.15 & 7.02 & 2.27 & 3.81 & 46.59 & 10.35 & 6.93 & 9.88 \\
Serv & 25.95 & 6.01 & 3.86 & 0.96 & 15.39 & 32.85 & 5.74 & 1.23 \\
Imp & 21.72 & 5.93 & 8.31 & 1.63 & 10.80 & 11.38 & 30.49 & 5.73 \\
\hline
\end{tabular}

Period 2: Variance decomposition after 12 periods with Cholesky ordering: GDP, semi-durable consumption, consumption of services, community services, financial services, mining, transport and imports 


\begin{tabular}{|crrrrrrrrr|}
\hline & \multicolumn{7}{c}{ Period 3 } \\
\hline GDP & Com & Fin serv & Trans & Man & Dur cons & Imp & Exp \\
GDP & 38.74 & 1.45 & 4.48 & 16.00 & 6.82 & 30.01 & 0.26 & 2.25 \\
Com & 19.22 & 55.70 & 4.29 & 5.41 & 1.60 & 7.98 & 5.11 & 0.69 \\
Tin serv & 13.16 & 0.74 & 46.08 & 21.66 & 1.07 & 15.16 & 0.23 & 1.90 \\
Mans & 20.48 & 1.87 & 13.63 & 46.01 & 4.35 & 12.97 & 0.54 & 0.15 \\
Dur cons & 12.53 & 1.98 & 4.86 & 29.33 & 10.52 & 39.33 & 0.32 & 1.11 \\
Imp & 7.24 & 2.93 & 38.22 & 21.91 & 1.84 & 9.35 & 12.06 & 6.44 \\
Exp & 8.84 & 5.01 & 2.59 & 14.41 & 17.36 & 4.18 & 7.31 & 40.30 \\
\hline
\end{tabular}

Period 3: Variance decomposition after 12 periods with Cholesky ordering: GDP, durable consumption, community services, financial services, transport, manufacturing imports as well as exports

In the second period the gaps for semi-durable consumption and services together explain approximately 25 per cent of the variance of the real GDP gap in the second period. Financial services explain a further 12 per cent. In the third period the gap for durable consumption explains 30 per cent of the forecast error variance of the real GDP gap and 23.6 per cent of the forecast error variance of the manufacturing gap (see Table 6). Note that in the third period exports do not explain much of the forecast error variance of any of the variables except its own.

\subsection{VARs using the asset type components of investments}

The investment gap variables in this subsection are defined in terms of asset types. In the first period VAR they are construction equipment, machinery, as well as residential and nonresidential buildings. In the second period VAR the investment gap variables include machinery, residential and non-residential buildings and transport equipment. In the third period only residential and non-residential buildings are included. Again the lag lengths of the VARs were selected on the basis of the information criteria. As such, the lag lengths selected for the VARs for the first, second and third periods, were one, four and two.

Using the 50 per cent cut-off point, the gaps for real GDP, durable consumption and construction investment were exogenous in the Granger sense in the first period (see Table 7). During the first period the durable consumption gap explained 21.9 per cent of the forecast error variance of the real GDP gap, 44.8 per cent of the machinery investment gap, 43 per cent of the investment in residential buildings gap and 38.7 per cent of the import gap.

In the second period, using the 50 per cent cutoff point, the gaps for real GDP and investment in residential buildings are exogenous, while the real GDP gap explains 29.1 per cent of the forecast error variance of imports (Table 7). In the third period the durable consumption gap explain 35.3 per cent of the forecast error variance of the real GDP gap, 34.3 per cent of the residential buildings gap and 23.3 per cent of the non-residential buildings gap. It also explains 48.6 per cent of its own forecast error variance, rendering it borderline exogenous. The real GDP gap explain a further 14.4 per cent of the durable consumption goods gap, while the gap of investment in non-residential buildings explains 31.8 per cent of the forecast error variance of the durable consumption gap, and 19.8 per cent and 19.9 per cent of the forecast error variances of the real GDP gap and investment in residential buildings. Note again that the exports gap in the third period does not explain much of the forecast error variance of any of the other variables, except its own. 


\section{Table 7}

Variance decomposition: Periods 1-3

\begin{tabular}{|cccccccc|}
\hline & \multicolumn{7}{c|}{ Period 1 } \\
\hline GDP & Dur cons & Const & Mach & Res & Non-res & Imports \\
Dur cons & 59.31 & 21.93 & 2.07 & 0.58 & 2.47 & 9.19 & 4.45 \\
Const & 0.44 & 81.83 & 0.75 & 1.38 & 2.31 & 6.35 & 6.94 \\
Mach & 3.61 & 10.99 & 71.83 & 0.39 & 6.36 & 1.29 & 5.53 \\
Res & 2.10 & 41.83 & 0.82 & 36.12 & 2.87 & 11.51 & 4.75 \\
Non-res & 1.87 & 22.20 & 4.29 & 6.50 & 24.71 & 36.25 & 4.19 \\
Imports & 10.59 & 38.68 & 3.90 & 0.32 & 3.52 & 6.86 & 36.13 \\
\hline
\end{tabular}

Period 1: Variance decomposition after 12 periods with Cholesky ordering: GDP, durable consumption, construction, machinery, residential and non-residential investment, as well as imports

\begin{tabular}{|crrrrrrrr|}
\hline & \multicolumn{7}{c|}{ Period 2 } \\
\hline GDP & Mach & Res & Non-res & Transp eq & S-dur cons & Serv & Imp \\
Mach & 53.99 & 5.47 & 0.83 & 2.65 & 1.73 & 17.41 & 5.82 & 12.10 \\
Res & 26.17 & 34.87 & 11.80 & 3.60 & 4.07 & 2.34 & 3.83 & 13.33 \\
Non-res & 22.28 & 17.35 & 11.56 & 35.19 & 2.62 & 1.25 & 2.47 & 7.29 \\
Transp eq & 15.71 & 8.59 & 9.93 & 4.80 & 31.82 & 10.94 & 5.43 & 12.77 \\
S-dur cons & 31.07 & 2.75 & 10.10 & 1.90 & 1.80 & 28.77 & 7.68 & 15.94 \\
Serv & 20.80 & 6.09 & 8.65 & 3.25 & 7.15 & 9.36 & 29.04 & 15.67 \\
Imp & 29.09 & 5.62 & 5.57 & 4.81 & 4.96 & 18.52 & 6.52 & 24.92 \\
\hline
\end{tabular}

Period 2: Variance decomposition after 12 periods with Cholesky ordering: GDP, semi-durable consumption, consumption of services, machinery, residential and non-residential investment and transport equipment

\begin{tabular}{|ccccccccc|}
\hline \multicolumn{7}{c|}{ Period 3 } \\
\hline GDP & GDP & Res & Non-res & Transp eq & Dur cons & Imp & Exp \\
Res & 36.24 & 2.49 & 19.81 & 1.83 & 35.30 & 1.92 & 2.40 \\
Non-res & 17.48 & 19.49 & 19.93 & 7.20 & 34.26 & 1.12 & 0.53 \\
Transp eq & 12.71 & 3.81 & 55.43 & 1.03 & 23.29 & 3.06 & 0.67 \\
Dur cons & 14.41 & 0.94 & 31.77 & 1.71 & 48.56 & 2.18 & 0.43 \\
Imp & 7.54 & 8.13 & 12.24 & 32.26 & 18.41 & 16.88 & 4.53 \\
Exp & 4.34 & 16.81 & 4.46 & 29.33 & 2.95 & 3.80 & 38.32 \\
\hline
\end{tabular}

Period 3: Variance decomposition after 12 periods with Cholesky ordering: GDP, durable consumption, residential and non-residential investment and transport equipment, imports as well as exports 
6

\section{Conclusion}

The above analysis highlights a few key aspects of the South African business cycle and how it changed when comparing the periods 1960:3 to $1976: 2,1976: 3$ to $1994: 1$ and $1994: 2$ to 2006:2. The analysis indicates that some of those components of GDP that experienced a large decrease in their standard deviations are also components of which the gaps display statistically significant and relatively sizable correlation coefficients with the real GDP gap. In the second and third periods these would include durable consumption, manufacturing investment, as well as investment in machinery and non-residential buildings. The real GDP gap also displayed a high correlation coefficient in the second and third periods with the gaps of imports, non-durable consumption, investment in the financial services sector, as well as investment in residential buildings.

The Granger causality tests indicate that in the third period only the gaps for consumption, and more specifically durable consumption, and investment in the manufacturing sector, as well as investment in non-residential buildings Granger cause the real GDP gap. This means that these are the only variables of which changes precede the changes in the real GDP gap. The variance decomposition support the Granger causality findings and, as such, provide further evidence of the key role played by semidurable consumption in the second period and durable consumption in the third period. These findings also point to the possible roles of these consumption components in driving the South African business cycle (even though durable consumption constitutes only about 12 per cent of total consumption). The variance decompositions also highlight the small role that exports played as driver in South Africa and as explanation for the business cycle. The key role of consumption and the small roles of exports and investment are rather surprising as conventional wisdom and a priori theory often assumes or postulates that changes in the investment gap and exports should lead changes in the real GDP gap.
Volatility decreased significantly from the second to the third period. As mentioned, it seems that the reduction in the volatility of GDP in South Africa can be traced to the reduction in the volatility of household consumption (durables and services), together with the decreases in the standard deviations of investment in machinery, non-residential buildings and transport equipment, most notably manufacturing investment. Sectors dominated by government, such as electricity and transport, did not contribute to the decrease in volatility.

\section{Endnotes}

1 A companion paper focuses on the relationship between the real GDP gap and variables other than national account variables.

2 Cyclical GDP can also be obtained using for instance a production function approach. However, this can only be applied to the GDP series and not the other series used. For the purposes of this paper, the same detrending technique had to be applied to all time-series used in the paper to ensure consistency. The Baxter-King BP filter could also be used, though the majority of the literature using statistical filters, selected the Hodrick-Prescott filter. As a result, this paper also uses the Hodrick-Prescott filter. This filter is a time-series smoothing technique where the smoothed time-series is obtained from selecting $s$ so as to minimise $\sum_{t=1}^{T}\left(y_{t}-s_{t}\right)^{2}+\lambda \sum_{t=2}^{T-1}\left(\left(s_{t+1}-s_{t}\right)-\left(s_{t}-s_{t-1}\right)\right)^{2}$, where $y$ is the time-series to smooth, $s$ is smoothed series and $\lambda$ is the smoothing parameter. For quarterly data the convention is to set $\lambda=1600$. This convention is followed in this paper. Note that due to the endpoint problem of the HP filter, some observations at both ends have been dropped.

3 For the latter approach this paper ignored peaks and troughs smaller than 0.01 in absolute terms.

4 An alternative approach is to calculate the correlation coefficients between the growth rates of variables. However, as Barrel and Gottschalk (2004:101) note, the use of growth rates is problematic given that the long-term component of the data might pollute the cyclical pattern of the growth rates. The second alternative would be to remove the cyclical component of the growth rates before calculating the correlation coefficients between the growth cycles. In preparing this paper both the gap variables and the growth cycles were calculated and used for the 
correlations and the volatility measures. Because both sets of calculations yield very similar results this paper uses only the gap variables.

5 However, note that although there is no discernable correlation between the investment gap of the electricity sector and the GDP gap, Odhiambo (2009) found a strong bi-directional causal relationship between economic growth and electricity consumption.

6 My thanks to Meshach Aziakpono for bringing this paper to my attention.

7 However, the tables containing the VAR results are available from the author on request. Note that the VAR residual serial correlation LM Tests indicated no serial correlation problems at a 5 per cent level for any of the VARs. In addition, the joint test for heteroskedasticity indicates no heteroskedasticity at a 5 per cent level in any of the VARs.

\section{References}

BARR, G. \& KANTOR, B. 2002. The South African economy and its asset markets. South African Journal of Economics, 70(1): 53-77.

BARRELL, R. \& GOTTSCHALK, S. 2004. The volatility of the output gap in the G7. National Institute Economic Review, 188: 100-7.

BERGMAN, U.M, BORDO, M.D. \& JONUNG, L. 1998. Historical evidence on business cycles: The international experience. In Jeffrey, C. and Schuh, S. (eds.) Beyond shocks: What causes business cycles? Federal Reserve Bank of Boston, Conference Series, (4): 65-113. BLANCHARD, O. \& SIMON, J. 2001. The long and large decline in US output volatility. Brookings Papers on Economic Activity, 2001(1): 135-164.

BURNS, A.F. \& MITCHELL, W.C. 1946. Measuring business cycles. National Bureau of Economic Research: New York.

DOYLE, B.M. \& FAUST, J. 2002. An investigation of co-movements among the growth rate of the G7 countries. Federal Reserve Bulletin, (Oct): 427-37. DU PLESSIS, S.A. 2006. Reconsidering the business cycle and stabilisation policies in South Africa. Economic Modelling, 23, 761-74.

DU PLESSIS, S.A. \& SMIT, B.W. 2007.

Countercyclical monetary policy in South Africa. Studies in Economics and Econometrics, 31(1): 79-98. DU PLESSIS, S., SMIT, B, \& STURZENEGGER, F. 2007. The cyclicality of monetary and fiscal policy in South Africa since 1994. South African Journal of Economics, 75(3): 391-411.

GAVIN, W.T. \& KYDLAND, F.E. 2000. Nominal facts and the October 1979 policy change. The Federal Reserve Bank of St. Louis. Working paper, no 2000-013A.
GORDON, R.J. 2005. What caused the decline in US business cycle volatility? NBER Working Paper, no 11777 (Nov).

KABUNDI, A. 2009. Synchronisation between South Africa and the US: A structural dynamic factor analysis. South African Journal of Economics, 77(1): 1-27. KAHN, J.A, MCCONNELL, M.M. \& PEREZQUIROS, G. 2002. On the causes of the increased stability of the US economy. The Federal Reserve Bank of New York Policy Review, (May): 183-202. KAHN, J.A, MCCONNELL, M.M. \& PEREZQUIROS, G. 2001. Inventories and the information revolution: Implications for output volatility. s.l. KYDLAND, F.E. \& PRESCOTT, E.C. 1990. Business cycles: Real facts and a monetary myth Federal Reserve Bank of Minneapolis, Quarterly Review, 14: 3-18. MCCONNELL, M.M. \& PEREZ-QUIROS, G. 2000. Output fluctuations in the United States: What has changed since the early 1980s? The American Economic Review, 90(5): 1464-1476.

ODHIAMBO, N.M. 2009. Electricity consumption and economic growth in South Africa: A trivariate causality test. Energy Economics, 31: 635-40.

RAMOS, F.F.R. 2003. Forecasts of market shares from VAR and BVAR models: A comparison of their accuracy. International Journal of Forecasting, 19: 95-110. ROMER, C.D. 1999. Changes in business cycles:

Evidence and explanations. The Journal of Economic Perspectives, 13(2): 23-44.

SOUTH AFRICAN RESERVE BANK. 2007. Online data download facility. Online: www.reservebank.co.za. STOCK, J.H. \& WATSON, M.W. 2003a. Has the business cycle changed? In Monetary policy and uncertainty: Adapting to a changing economy. Federal Reserve Bank of Kansas City, 9-56.

STOCK, J.H. \& WATSON, M.W. 2003b. Understanding changes in international business cycle dynamics. NBER Working Paper, no 9859 (Jul).

TAYLOR, J.B. 1998. An historical analysis of monetary policy rules. NBER Working Paper, no 6768 (Oct). TAYLOR, J.B. 2000. Recent development in the use of monetary policy rules. A written version of a dinner speech given at the conference, Inflation targeting and monetary policies in emerging economies, at the Central Bank of the Republic of Indonesia, Jakarta, Indonesia, July 13-14, 2000. THORNTON, J. 2007. On the cyclicality of South African fiscal policy. South African Journal of Economics, 75(2): 258-64.

VENTER, J.C. 2005. Reference turning points in the South African business cycle: Recent developments. Quarterly Bulletin (Sept) South African Reserve Bank. WARNOCK, M.V.C. \& WARNOCK, F.E. 2000. The declining volatility of US employment: Was Arthur Burns right? Board of Governors of the Federal Reserve System, International Finance Discussion Papers, no 677 (Aug). 


\section{Appendix A}

\section{Granger causality tests}

The columns headed by ' $\mathrm{X} Y$ ' reports the probability of making a mistake by rejecting the null hypothesis that a variable such as the real consumption gap, denoted by $\mathrm{X}$, does not Granger cause the real GDP gap, denoted by $\mathrm{Y}$. The columns, headed by ' $\mathrm{Y} X$ ' report the reverse causality result. Using a 5 per cent significance level, probability values of less than 0.05 indicate that there is evidence that, for instance, changes in the real consumption gap precede changes in the real GDP gap. These statistically significant results are shaded in grey.

\section{Table A1}

Granger causality between the GDP gap and the GDP component gaps

\begin{tabular}{|c|c|c|c|c|c|c|c|c|c|c|c|c|}
\hline & \multicolumn{4}{|c|}{ Period 1} & \multicolumn{4}{|c|}{ Period 2} & \multicolumn{4}{|c|}{ Period 3} \\
\hline & \multicolumn{2}{|c|}{ Granger (2) } & \multicolumn{2}{|c|}{ Granger (4) } & \multicolumn{2}{|c|}{ Granger (2) } & \multicolumn{2}{|c|}{ Granger (4) } & \multicolumn{2}{|c|}{ Granger (2) } & \multicolumn{2}{|c|}{ Granger (4) } \\
\hline & XY & $\mathbf{Y X}$ & $\mathbf{X Y}$ & $\mathbf{Y X}$ & $X Y$ & $\mathbf{Y X}$ & $\mathbf{X Y}$ & $\mathbf{Y X}$ & $\mathbf{X Y}$ & $\mathbf{Y X}$ & $\mathbf{X Y}$ & $\mathbf{Y X}$ \\
\hline C & 0.03 & 0.43 & 0.06 & 0.17 & 0.64 & 0.07 & 0.44 & 0.01 & 0.00 & 0.01 & 0.02 & 0.03 \\
\hline G & 0.60 & 0.66 & 0.41 & 0.65 & 0.29 & 0.41 & 0.18 & 0.25 & 0.08 & 0.59 & 0.19 & 0.79 \\
\hline I & 0.78 & 0.17 & 0.03 & 0.29 & 0.40 & 0.00 & 0.21 & 0.23 & 0.86 & 0.02 & 0.86 & 0.06 \\
\hline $\mathbf{X}$ & 0.08 & 0.06 & 0.06 & 0.30 & 0.25 & 0.81 & 0.43 & 0.36 & 0.47 & 0.00 & 0.37 & 0.00 \\
\hline $\mathbf{M}$ & 0.01 & 0.11 & 0.02 & 0.10 & 0.04 & 0.00 & 0.22 & 0.00 & 0.42 & 0.01 & 0.39 & 0.00 \\
\hline
\end{tabular}

Granger causality tests: Probabilities lower than 5 per cent indicated by shaded area

\section{Table A2}

Granger causality between the real GDP gap and the components of consumption

\begin{tabular}{|c|c|c|c|c|c|c|c|c|c|c|c|c|}
\hline & \multicolumn{4}{|c|}{ Period 1} & \multicolumn{4}{|c|}{ Period 2} & \multicolumn{4}{|c|}{ Period 3} \\
\hline & \multicolumn{2}{|c|}{ Granger (2) } & \multicolumn{2}{|c|}{ Granger (4) } & \multicolumn{2}{|c|}{ Granger (2) } & \multicolumn{2}{|c|}{ Granger (4) } & \multicolumn{2}{|c|}{ Granger (2) } & \multicolumn{2}{|c|}{ Granger (4) } \\
\hline & $\mathbf{X Y}$ & $\mathbf{Y X}$ & $\mathbf{X Y}$ & $\mathbf{Y X}$ & $\mathbf{X Y}$ & $\mathbf{Y X}$ & $\mathbf{X Y}$ & $\mathbf{Y X}$ & $\mathbf{X Y}$ & $\mathbf{Y X}$ & $\mathbf{X Y}$ & $\mathbf{Y X}$ \\
\hline Durable & 0.00 & 0.93 & 0.01 & 0.40 & 0.14 & 0.38 & 0.12 & 0.13 & 0.00 & 0.05 & 0.00 & 0.08 \\
\hline $\begin{array}{l}\text { Semi- } \\
\text { durable }\end{array}$ & 0.36 & 0.29 & 0.13 & 0.62 & 0.15 & 0.48 & 0.00 & 0.12 & 0.63 & 0.72 & 0.58 & 0.88 \\
\hline $\begin{array}{l}\text { Non- } \\
\text { durable }\end{array}$ & 0.37 & 0.16 & 0.57 & 0.30 & 0.28 & 0.03 & 0.60 & 0.11 & $0 . .26$ & 0.10 & 0.62 & 0.27 \\
\hline Services & 0.26 & 0.09 & 0.32 & 0.42 & 0.11 & 0.00 & 0.43 & 0.01 & $0 . .29$ & 0.34 & 0.52 & 0.38 \\
\hline
\end{tabular}

Granger causality tests: Probabilities lower than 5 per cent indicated by shaded area 


\section{Table A3}

Granger causality tests between the real GDP gap and the sectoral components of investment

\begin{tabular}{|c|c|c|c|c|c|c|c|c|c|c|c|c|}
\hline & \multicolumn{4}{|c|}{ Period 1} & \multicolumn{4}{|c|}{ Period 2} & \multicolumn{4}{|c|}{ Period 3} \\
\hline & \multicolumn{2}{|c|}{ Granger (2) } & \multicolumn{2}{|c|}{ Granger (4) } & \multicolumn{2}{|c|}{ Granger (2) } & \multicolumn{2}{|c|}{ Granger (4) } & \multicolumn{2}{|c|}{ Granger (2) } & \multicolumn{2}{|c|}{ Granger (4) } \\
\hline & $\mathbf{X Y}$ & $\mathbf{Y X}$ & $\mathbf{X Y}$ & $\mathbf{Y X}$ & XY & $\mathbf{Y X}$ & $\mathbf{X Y}$ & $\mathbf{Y X}$ & $\mathbf{X Y}$ & $\mathbf{Y X}$ & $\mathbf{X Y}$ & $\mathbf{Y X}$ \\
\hline Community & 0.11 & 0.17 & 0.06 & 0.07 & 0.41 & 0.00 & 0.87 & 0.00 & 0.62 & 0.05 & 0.86 & 0.01 \\
\hline Electricity & 0.01 & 0.87 & 0.01 & 0.76 & 0.83 & 0.58 & 0.85 & 0.72 & 0.22 & 0.63 & 0.40 & 0.46 \\
\hline $\begin{array}{l}\text { Financial } \\
\text { services }\end{array}$ & 0.02 & 0.04 & 0.04 & 0.13 & 0.02 & 0.05 & 0.03 & 0.22 & 0.10 & 0.03 & 0.19 & 0.29 \\
\hline $\begin{array}{l}\text { Manufactu- } \\
\text { ring }\end{array}$ & 0.10 & 0.80 & 0.07 & 0.997 & 0.66 & 0.10 & 0.66 & 0.12 & 0.61 & 0.26 & 0.03 & 0.58 \\
\hline Mining & 0.47 & 0.05 & 0.23 & 0.07 & 0.12 & 0.01 & 0.16 & 0.03 & 0.11 & 0.25 & 0.11 & 0.15 \\
\hline Transport & 0.98 & 0.31 & 0.63 & 0.09 & 0.22 & 0.05 & 0.76 & 0.03 & 0.53 & 0.01 & 0.89 & 0.08 \\
\hline
\end{tabular}

Granger causality tests: Probabilities lower than 5 per cent indicated by shaded area

\section{Table A4}

Granger causality tests between the real GDP gap and the asset components of investment

\begin{tabular}{|c|c|c|c|c|c|c|c|c|c|c|c|c|}
\hline & \multicolumn{4}{|c|}{ Period 1} & \multicolumn{4}{|c|}{ Period 2} & \multicolumn{4}{|c|}{ Period 3} \\
\hline & \multicolumn{2}{|c|}{ Granger (2) } & \multicolumn{2}{|c|}{ Granger (4) } & \multicolumn{2}{|c|}{ Granger (2) } & \multicolumn{2}{|c|}{ Granger (4) } & \multicolumn{2}{|c|}{ Granger (2) } & \multicolumn{2}{|c|}{ Granger (4) } \\
\hline & $\mathbf{X Y}$ & $\mathbf{Y X}$ & $\mathbf{X Y}$ & $\mathbf{Y X}$ & $\mathbf{X Y}$ & $\mathbf{Y X}$ & $\mathbf{X Y}$ & $\mathbf{Y X}$ & $\mathbf{X Y}$ & $\mathbf{Y X}$ & $\mathbf{X Y}$ & $\mathbf{Y X}$ \\
\hline Construction & 0.25 & 0.26 & 0.08 & 0.00 & 0.86 & 0.07 & 0.84 & 0.22 & 0.53 & 0.34 & 0.30 & 0.23 \\
\hline Machinery & 0.14 & 0.50 & 0.03 & 0.32 & 0.84 & 0.02 & 0.61 & 0.04 & 0.90 & 0.19 & 0.29 & 0.18 \\
\hline $\begin{array}{l}\text { Non- } \\
\text { residential }\end{array}$ & 0.38 & 0.33 & 0.01 & 0.45 & 0.08 & 0.00 & 0.67 & 0.01 & 0.05 & 0.14 & 0.02 & 0.07 \\
\hline Residential & 0.15 & 0.01 & 0.04 & 0.01 & 0.19 & 0.01 & 0.61 & 0.07 & 0.10 & 0.00 & 0.27 & 0.01 \\
\hline Transport & 0.77 & 0.24 & 0.99 & 0.31 & 0.67 & 0.02 & 0.40 & 0.12 & 0.97 & 0.01 & 0.89 & 0.02 \\
\hline
\end{tabular}

Granger causality tests: Probabilities lower than 5 per cent indicated by shaded area 


\section{Appendix B}

Standard deviations

\section{Table B1}

Standard deviations of GDP and the components of aggregate expenditure

\begin{tabular}{|l|l|l|l|l|l|l|}
\hline & C & G & I & $\mathbf{X}$ & $\mathbf{M}$ & Real GDP \\
\hline St dev 1 & 0.019 & 0.036 & 0.058 & 0.038 & 0.099 & 0.013 \\
St dev 2 & 0.028 & 0.026 & 0.071 & 0.053 & 0.102 & 0.021 \\
St dev 3 & 0.011 & 0.018 & 0.034 & 0.046 & 0.046 & 0.009 \\
\hline F test 1 \& 2 & 0.00 & 0.01 & 0.09 & 0.01 & 0.80 & 0.00 \\
F test 2 \& 3 & 0.00 & 0.01 & 0.00 & 0.31 & 0.00 & 0.00 \\
\hline F test 1 \& 3 & 0.00 & 0.00 & 0.00 & 0.16 & 0.00 & 0.01 \\
\hline
\end{tabular}

St $\operatorname{dev} 1,2$ and 3: Standard deviation in periods 1, 2 and 3; F test: Null hypothesis of F-test is that the variances of two periods (say periods 1 and 2) are statistically not significantly different. Thus, rejection of the null hypothesis indicates that the variances are not the same. Probabilities lower than 5 per cent indicated by shaded area.

\section{Table B2}

Standard deviations of the components of consumption

\begin{tabular}{|c|c|c|c|c|}
\hline & Durable & Non-durable & Semi-durable & Services \\
\hline St dev 1 & 0.079 & 0.026 & 0.016 & 0.021 \\
\hline St dev 2 & 0.104 & 0.044 & 0.020 & 0.030 \\
\hline St dev 3 & 0.048 & 0.024 & 0.014 & 0.008 \\
\hline F test $1 \& 2$ & 0.03 & 0.05 & 0.00 & 0.01 \\
\hline F test $2 \& 3$ & 0.00 & 0.00 & 0.00 & 0.00 \\
\hline$F$ test $1 \& 3$ & 0.00 & 0.27 & 0.57 & 0.00 \\
\hline
\end{tabular}

For explanation of abbreviations, see notes to Table B1.

\section{Table B3}

Standard deviations of the sectoral components of investment

\begin{tabular}{|l|c|c|c|c|c|c|}
\hline & Community & Electricity & Financial & Manufacturing & Mining & Transport \\
\hline St dev 1 & 0.077 & 0.111 & 0.093 & 0.124 & 0.157 & 0.127 \\
St dev 2 & 0.066 & 0.127 & 0.091 & 0.167 & 0.125 & 0.145 \\
St dev 3 & 0.044 & 0.135 & 0.050 & 0.043 & 0.083 & 0.124 \\
F test 1 \& 2 & 0.23 & 0.28 & 0.84 & 0.02 & 0.06 & 0.29 \\
F test 2 \& 3 & 0.00 & 0.61 & 0.00 & 0.00 & 0.00 & 0.25 \\
F test 1 \& 3 & 0.00 & 0.13 & 0.00 & 0.00 & 0.00 & 0.87 \\
\hline
\end{tabular}

For explanation of abbreviations, see notes to Table B1. 


\section{Table B4}

Standard deviations of the asset components of investment

\begin{tabular}{|l|c|c|c|c|c|}
\hline & Construction & Machinery & $\begin{array}{c}\text { Non- } \\
\text { residential }\end{array}$ & Residential & Transport \\
\hline St dev 1 & 0.070 & 0.072 & 0.076 & 0.085 & 0.108 \\
St dev 2 & 0.101 & 0.090 & 0.111 & 0.074 & 0.136 \\
St dev 3 & 0.073 & 0.038 & 0.057 & 0.050 & 0.079 \\
F test 1 \& 2 & 0.00 & 0.07 & 0.00 & 0.24 & 0.06 \\
F test 2 \& 3 & 0.02 & 0.00 & 0.00 & 0.00 & 0.00 \\
F test 1 \& 3 & 0.75 & 0.00 & 0.04 & 0.00 & 0.02 \\
\hline
\end{tabular}

For explanation of abbreviations, see notes to Table B1. 


\section{Appendix C \\ Impulse-responses for period 2}

To interpret heading, 'Consumption to GDP' means the response of the consumption gap to a one standard deviation shock to the GDP gap.

GDP to GDP

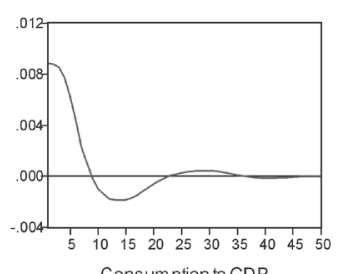

Consumption to GDP

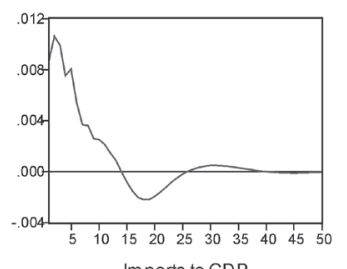

Imports to GDP

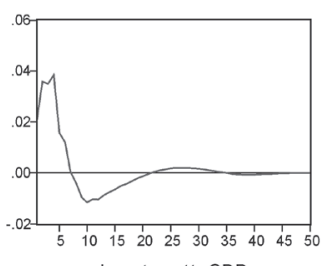

Investmentto GDP

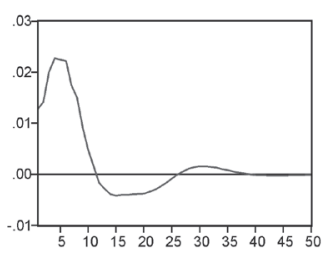

GDP to Consum ption
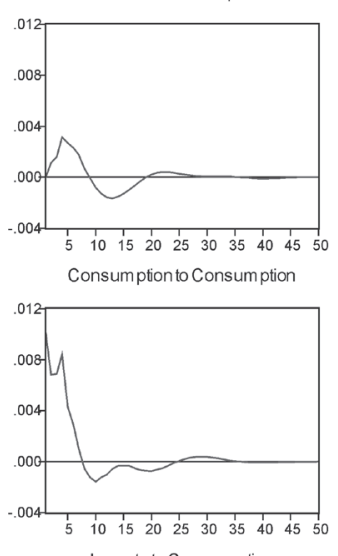

Im ports to Consum ption

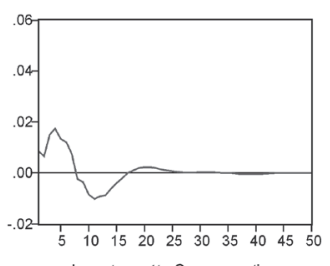

Investmentto Consumption

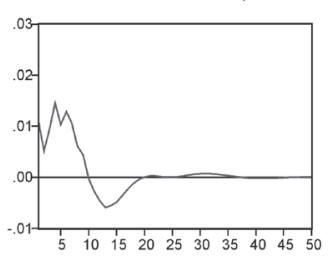

GDP to Im ports

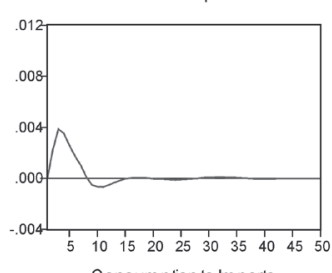

Consumption to Im ports

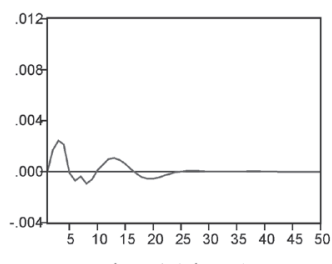

Im ports to Im ports

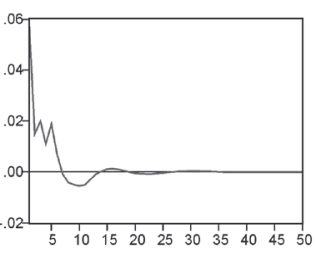

Inves tm ent to Im ports

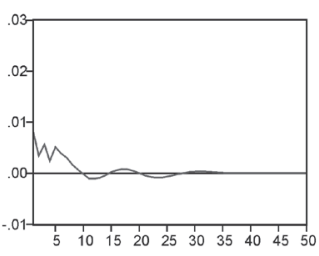

GDP to Investment

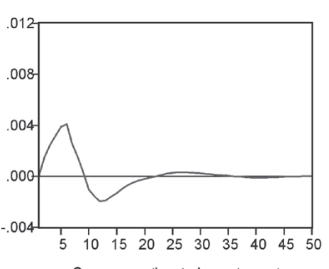

Consumption to Investment

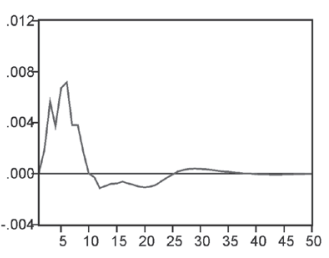

Im ports to Investment

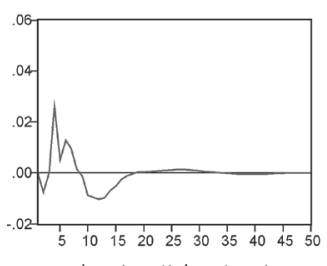

Inves tmento Investment

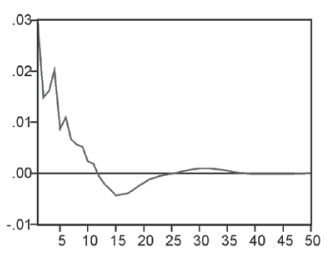




\section{Appendix D}

Impulse-responses for period 3

To interpret heading, 'Consumption to GDP' means the response of the consumption gap to a one standard deviation shock to the GDP gap.

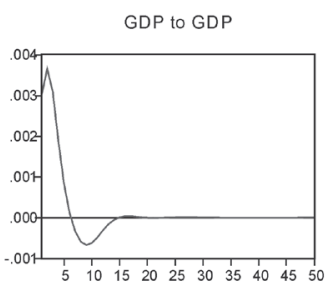

Consumption to GDP

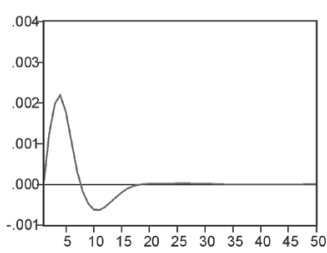

Im ports to GDP

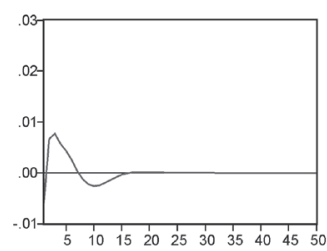

Investment to GDP

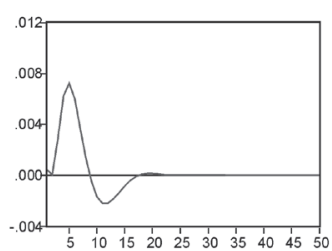

GDP to Consumption

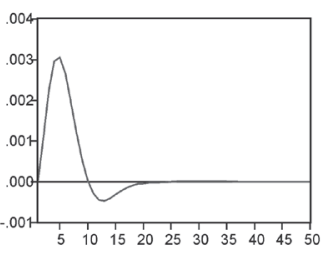

Consumption to Conumpstion

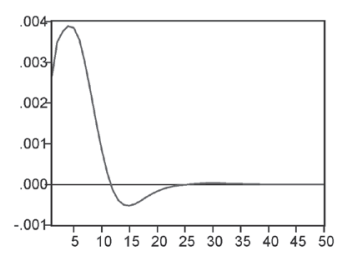

Imports to Consum ption

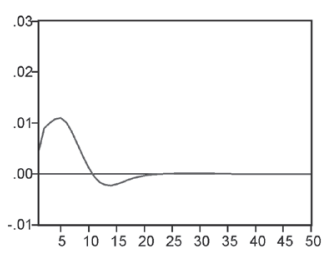

Investmentto Consumption

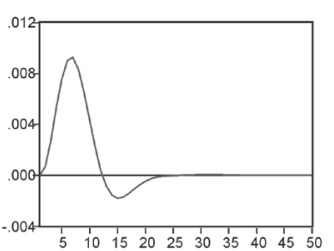

GDP to Im ports

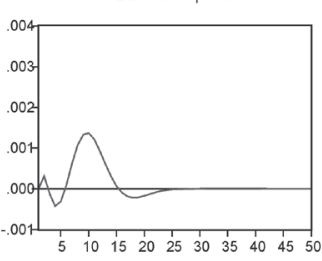

Consumption to Im ports

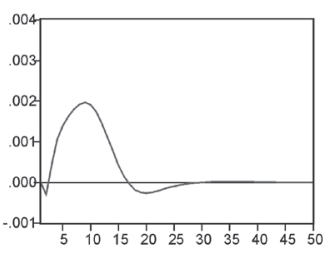

Im ports to Im ports

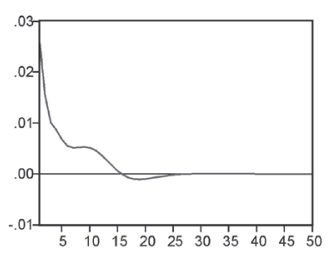

Investment to Im ports

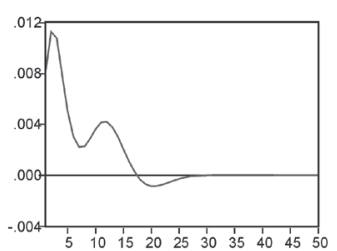

GDP to Investment

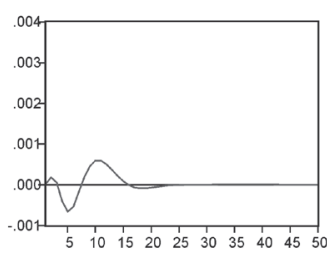

Consumption to Investment

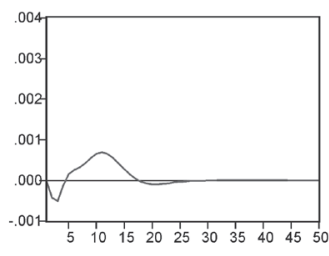

Im ports to Investment

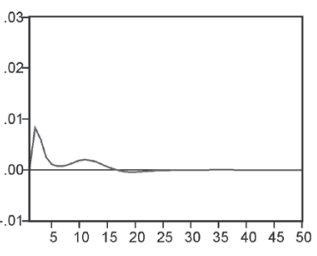

Investment to Investment

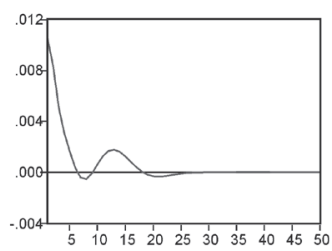

